\title{
International Investment in Education for Development: Public Good or Economic Tool?
}

\author{
Alexandra Draxler
}

\begin{abstract}
Is education a human right or a driver of economic development? How international organisations frame their strategies is determined to a great extent by their response to this question. This chapter argues that a sound education system is one that is rightsbased and seeks to achieve social cohesion, equality of access, and equity of opportunity. Efforts to generate economic returns from education to individuals and societies, while important, should not dominate development policies. As the post-2015 Development Agenda emerges, tensions between those who perceive education as a human right and those who see it as a tool of economic development are increasingly coming to the fore, notably due to growing influence and interest among international private entities, both foundations and corporations, in steering the agenda towards the development of market opportunities. The author argues that preserving the role of the state as the ultimate democratic arbiter of rights, equality, and equity is the only way, albeit imperfect, of guaranteeing education as a public good.
\end{abstract}

Introduction

What are the purposes of education? An implicit answer to this question is the foundation for all public policy, private investment, and choices made by individuals concerning education for them or their children. The evolving policies for development cooperation in education respond to and reflect the underlying ideologies of the main protagonists. These protagonists include the United Nations (UN) system (principally the United Nations Educational, Scientific and Cultural Organization (UNESCO)), the World Bank, bilateral donors, and civil society organisations. This chapter will look at some of the lessons pertinent to the next stage in international cooperation that aims to achieve universal quality education after 2015. It has three underlying themes that highlight inherent policy choices and tensions:

(c) Graduate Institute of International and Development Studies, 2014 | DOI 10.1163/9789004281158_004 This is an open access chapter distributed under the terms of the Creative Commons Attribution- 
- The tension between two visions of education - on the one hand, education as human right and an end in itself, and on the other, education as a tool for economic development.

- Evolving definitions of equity, fairness, and equal opportunity, including the opportunity for all to have access to organised learning opportunities throughout life.

- Standardised assessment, evaluation, and measuring, and how they both reflect and structure policies and learning opportunities.

The right to education was originally broadly defined as the right to schooling, ${ }^{1}$ and the right to schooling as a right that principally benefitted individuals. Demand for schooling has never ceased to grow. In spite of powerful economic and social obstacles and of criticisms of the imperfections of schools and school systems, parents and children continue to aspire to access ever-increasing levels of schooling and training. Targets for schooling continue to be the most scrutinised benchmarks for progress in education worldwide and meeting the aim of schooling for all has been arguably the dominant force to date in international education movements over the past twenty years. Education is, of course, much more than schooling, and although this chapter discusses mainly schooling, the tendencies it points out also apply to other kinds of training and lifelong learning opportunities.

This chapter identifies education as a public good. There is disagreement among experts on the validity of this claim. In the original and public-finance notion of public goods, they are non-rivalrous (use by one individual does not alter a good's availability to another individual) and non-excludable (they are freely available to all and cannot be restricted) (Samuelson, 1954). Knowledge, while commonly recognised as a public good, can be excludable. The classification of public services as public goods or non-public goods depends to a large extent on an ideological divide. On the one hand, there are those, including UN organisations, who support the notion that governments and international organisations are responsible for ensuring public services that are considered human rights, and are in consequence public goods. On the other, there are those who maintain that market forces can and should take care of many of these services, which are essentially private goods. Here we base our arguments on the United Nations Development Programme (UNDP) position

1 'Everyone has the right to education. Education shall be free, at least in the elementary and fundamental stages. Elementary education shall be compulsory.', United Nations, Universal Declaration of Human Rights (1948). http://www.un.org/en/documents/udhr/ (accessed on 24 April 2014). 
(Kaul, Grunberg et al., 1999) and the continued inclusion, by the UN system, of education among public goods.

Or take education, which benefits the person being educated. To calculate the benefits, we take the income a person earns over a lifetime with education, and subtract that which she would get without an education. But that figure does not tell the whole story. What about the numerous employers the person will have over a lifetime, and the savings realised because these employers do not have to train her in-house? What about the benefits that literacy brings to all the companies that rely on the written word to advertise? The benefits to those who issue public warnings, put out signs or seek to implement laws? If one were to put a figure on all these benefits, they would dwarf the amount that accrues strictly to the educated person. This difference between the public and the private benefits is called an externality. And because of its substantial externalities, education is a public good. (Kaul, Grunberg et al., 1999, p. xx)

\section{Defining Education's Role in Development}

In the years after World War II, and with growing force in the 1960s as the wave of African independence grew the number of sovereign nations by almost half in a decade, both economic growth and enthusiasm for the potential of global human rights - including the right to education-inspired the discourse and the policies of all those involved in international cooperation. Targets were set for universal schooling and adult literacy. A world in which education throughout life would be available for all and taken up by most was envisaged (Faure, Herrera et al., 1972). Literacy for all was a mobilising notion during the 1960s for a significant proportion of development programmes. Entire nations embarked on massive literacy programmes for everyone out of school, and some succeeded. ${ }^{2}$ Education was seen, by most actors and observers, as an integral feature and driver of the betterment of the human condition. Not all agreed that formal learning was the answer. Indeed, thinkers such as Paulo Freire and Ivan Illich favoured dismantling education systems as they existed in order to rebuild from the beginning on the basis of local needs and local effort to favour the fulfilment of individual potential (Gajardo, 1993; Gerhardt, 1993).

2 See UNESCO 50 Years of Education (online archives), http://www.unesco.org/education/ educprog/50y/brochure/tle/124.htm (accessed on 19 February 2014). 
Then, as public social sector spending came under scrutiny in both 'South' and 'North' during the 1970s, the scramble for economic arguments to support investment in education and health focused on outcomes the economic impact of which could be determined. Human capital had been defined and consecrated as a factor of economic prosperity (Vally and Spreen, 2012). Thus, academics, theorists, and eventually international policymakers developed concepts and translations into policies of 'manpower planning' (Samoff and Carrol, 2003), 'functional literacy', ${ }^{3}$ and 'rates of return' (Tilak, 2007b) on investment for various levels of education.

In addition to the economic arguments, though, the notion that development was a process of ensuring basic needs are met for all (including education) was initiated by the International Labour Organisation (ILO) in 1976. Basic needs appeared to unite humanistic and practical aims through a vision of development that could be quantified and itemised, and for many years, including at the Jomtien Conference and afterwards, this approach exerted significant influence (Emmerij, 2010) on the policies of international and bilateral aid agencies. Another school of thought criticised basic needs as an approach based on a consumerist view of development and advocated for an approach based on capabilities (Sen, 2003). In any case, the fulfilment of basic needs could be estimated in terms of the growth needed to achieve targets, and so employment became both 'a means and an end' (Emmerij, 2010, 1). In more recent years, as manpower planning has lost its appeal, marketplace notions of education provision and delivery have been touted whereby learners and their parents, through 'school choice', become consumers who are individually responsible for the design and wisdom of their trajectories. Recommendations by the World Bank for the allocation of public investment in education still lean heavily on notions of rates of return and on the idea that much of the provision of education should rely on market forces and private sector providers. When structural adjustment programmes in the 1980s and 1990s forced drastic reductions in public sector spending and proposed increased roles for private sector entities, opponents to such programmes foresaw with fury their long-term negative effects on education.

These contrasting philosophical and policy trends, with correspondingly competing agendas, have had significant influence on education policy and practice internationally. On the one hand, there has been a renewed commitment to basic education as a right both on the part of the international com-

3 It has to be said that the notion of functional literacy emerged partly as a response to the failure of many classical literacy programmes in impoverished environments where the skills of literacy had no immediate relevance or application. 
munity and on the part of governments. On the other, the search for greater accountability for education expenditure has often been played out in a search for functionality in terms of economic productivity. The notion of education being provided through marketplace mechanisms and of the learner as consumer to a large extent absolves the public sector for inequalities that originate outside the education system and persist or are aggravated through it. The justification of education streams, subjects, or levels in terms of rates of return implies lesser value for types of learning where rates of return are more elusive. Although rates of return are widely used by the World Bank, and references to rates of return have turned up in the report (High Level Panel on the post-2015 Development Agenda, 2013) tabled as a key document to inspire post-2015, they are subject to a great deal of controversy and criticism (Tinak, 2007a, 2007b). Use of rates of return has also has resulted in a wide and very successful push for a greater influence of the private sector in the provision of public goods, from the actual running of schools (Patrinos and Sosale, 2007), to the provision of vocational training (Adams, Middleton et al., 1992), to provision of learning materials and methods, and the devising of measurement and management tools. At the same time, while nominally defending a rightsbased approach, the UN (and UNESCO) have increasingly shown quite uncritical acceptance of the role of the private sector and welcomed market-based approaches (UN Global Compact, 2013; UNESCO, 2013).

\section{Tension or Equilibrium between Goals and Purposes}

It is only recently that significant policy attention has been devoted internationally to the sad fact that the expansion of education opportunities does not result in more equal opportunity or outcomes. The equilibrium between the dual aims of education in individual and societal development, in terms of access to and content of education, has naturally varied widely over time according to the nature of governments and to societal events. Furthermore, the issue of tackling within-country inequalities has been approached somewhat gingerly in development circles until recently.

As already stated, the notion that human capital is an important feature in economic growth was very important for post-World War II reconstruction and then as a tenet of development in general (Spalletti, 2008). Therefore, 'manpower' forecasting as a way of organising the post-primary levels of education systems became an accepted and influential technique used by governments with an interventionist economic tradition. This included decisions about the creation and placement of vocational training, numerus clausus at different 
levels of the system, and incentives to attract learners to specific areas that were viewed as under-served. Education planning became a permanent part of the public sector landscape as a management tool to match and evaluate aims, resources, and competencies over time.

Once education became 'both a sign of wealth and a source of it' (Spalletti, 2008), the goals of education became inextricably entwined, for public policy purposes, with notions of national prosperity and growth. People can be seen as more an instrument of progress, however that is defined in public policy terms, than the other way around. The relevance of education, once it is defined as relevance for the marketplace, can distort the process away from the realisation of individual potential.

\section{Some Milestone Reports}

One of the first analytical report on education worldwide was produced for a joint US - UNESCO effort in 1967. The International Conference on the World Crisis in Education announced a crisis and attributed it to the tension between demand and available resources, to societal inertia, and to not enough understanding and information about education as a system. The book (Coombs, 1968) that emerged from the background papers and the conference did not ignore individual aspirations and needs. It was nevertheless a heavily economically oriented analysis, working on an analytical framework of objectives $\rightarrow$ inputs $\rightarrow$ process $\rightarrow$ outputs. The book formulated recommendations for more international cooperation as a way of improving education worldwide. It was also influential in giving weight and momentum to the development of analytical tools and collaboration in the collection and use of data for educational planning and management, and by extension the measurement of the economic value of education.

Fifteen years later, partially in response to student and worker demonstrations and violence in many parts of the world at the end of the 1960s, a sevenman commission, brought together by UNESCO to reflect on the future of education, issued a report entitled 'Learning to Be' (Faure, Herrera et al., 1972). This report carried a powerful message of faith in humanity and of the role of education in bringing out the best in humanity. It was both a plea and an affirmation of the right of each person to receive an education that develops critical thinking and allows full realisation of individual potential. "The aim of development is the complete fulfilment of man, in all the richness of his personality, the complexity of his forms of expression and his various commitments - as individual, member of a family and of a community, citizen and 
producer, inventor of techniques and creative dreamer' (Faure, Herrera et al., 1972, 94). ${ }^{4}$

Around the same time, in 1971 (revised in 1974), the World Bank produced its first Education Sector Working Paper (World Bank, 1971). The paper talked about education largely in terms of production efficiencies: 'matching education with manpower needs', adapting content to the realities of primitive rural life, and positing that, given high youth unemployment, continued expansion of education systems would be unprofitable in the short term. At the time, nearly three-quarters of bank lending went to post-primary education. It is worth pointing out that educational television and programmed learning (for both of which countries took out large loans) were at the time completely unproven technologies for quality of education in wealthy countries, let alone poor ones. Their cost-benefit attraction for secondary schooling is still to be demonstrated to any scale.

Still, as a lender, the World Bank had not only to look for but to provide arguments for efficiencies in its social sector programmes in order to convince its board of the value of social sector support. It naturally looked at the inevitable resource constraints of poor countries that were already devoting 20 per cent of national budgets to education and could hardly aim at unlimited expansion of the education offer. The trade-off between quality and quantity was already very much present as an issue. The unavoidable financial constraints on education therefore provided the humus for the World Bank's thinking in which both rates of return and, ultimately, the expansion of sources of financing to embrace the private sector and privatisation sprouted and flourished.

At the end of the 1980s and the decade's period of structural adjustment, economic crisis, and stagnation in educational progress, UNESCO, United Nations International Children's Emergency Fund (UNICEF), UNDP, the United Nations Population Fund (UNFPA), and the World Bank joined forces to give a new impetus to the push for universal education. A secretariat was created under the leadership of Wadi Haddad, a senior World Bank official, to provide the conceptual and organisational underpinnings of a World Conference on Education for All (EFA), which took place in Jomtien, Thailand, in 1990. The background report of the conference (Secretariat of the World Conference on EFA, 1990), as well as the goals formulated and agreed by the conference itself (World Conference on Education for All, 1990) placed human development

4 It will not escape the attention of any reader that the equal rights of girls and women to participate fully in education did not become a serious preoccupation of international organisations until the 1980s with the gradual adoption of the Convention on the Elimination of all forms of Discrimination. 
and basic learning needs firmly at the centre of development discourse, and for the first time proposed not only aims but also funding strategies to reach universal basic education. An international consortium kept up this impetus with follow-up studies. Ten years later, in Dakar, Senegal, a review of progress led to revised goals and to a permanent monitoring process that is expressed in an annual report. ${ }^{5}$ These EFA reports have been influential, with annual updates of standard data and in-depth thematic reviews of particular challenges.

The notion of human development had joined the international development vocabulary, under the impetus of economist Mahbub ul Haq who pushed for an alternative to the purely economic models in vogue among funders. The UNDP Human Development report, launched in 1990, was influential in giving both ideological and factual ammunition to civil society organisations and policymakers regarding the inadequacy of structural adjustment, trickle-down economics, and laissez-faire in tackling inequality, lack of democracy, and weaknesses in the social fabric. Here is what it had to say about the conception and vision of the human development indicators in the first report: '[...] we are rediscovering the essential truth that people must be at the centre of all development. The purpose of development is to offer people more options [...] including long life, knowledge, political freedom, personal security, community participation and guaranteed human rights. People cannot be reduced to a single dimension as economic creatures' (UNDP, 1990, iii).

In the wake of the Jomtien Conference, and around twenty years after the publication of Learning to Be, UNESCO entrusted an independent commission of fifteen people, chaired by Jacques Delors, with the task of looking at the challenges of education for the twenty-first century. The commission's work consisted in hearings, and the examination of studies it requested. Its report (Delors, 1996) was a call for a humanistic, people-centred vision of education. It was framed in the light of, and was an alternative to, several decades of intense focus on the macro-economic benefits of schooling and training. Its foundation view of education, based on four pillars-learning to know, learning to do, learning to be, and learning to live together - resonated with a large constituency of educators, policymakers, and governments. Education was placed primarily in its social setting - in the light of the challenges of global interdependence, enhanced democratic participation, and sustainable development. Its plea was for the development of a learning society, in which citizens would be able and conscious actors in the construction of their environment and the world at large.

5 See documents from the World Education Forum, Dakar, http://www.unesco.org/education/ efa/wef_2000/(accessed on 8 May 2014). 
The World Bank's 1995 education strategy (World Bank, 1995), while sticking to its rates-of-return calculations and maintaining throughout the text that education is principally aimed at economic growth (co-defined with poverty reduction) and knowledge creation, softened much of its language to take on board notions of human development. It discovered the virtues of general secondary education, including in poor countries and for poor people. Its introduction gives a nod to the Delors report's 'four pillars' of learning: education produces knowledge, skills, values, and attitudes. Still, most of the justification of education remains based on calculations of its economic value.

As already mentioned, the launch of the EFA monitoring system has federated and driven much of the thinking and discussion internationally since 2002. Its thematic reports (Education Global Monitoring Report Team, 2013) are firmly grounded in a rights-based approach, building on the Delors report's four pillars and inspired by Amartya Sen's theoretical development of the notion of individual capability (Unterhalter, 2003).

On the donor side, the Fast Track Initiative that has become the Global Partnership for Education has developed its own monitoring mechanisms, and launched in 2012 a series of annual reports (Global Partnership for Education, 2012) on progress towards national education sector plans on access and learning outcomes. The indicators regarding enrolments and quality certainly focus on the right to education and on learning outcomes, rather than economic indicators.

However, beyond unity of discourse, as the World Bank has moved to using language more friendly to the notions of human development, the UN and its specialised agencies have enthusiastically embraced collaboration with the private sector.

It was at the 1990 World Conference on EFA that there was the first notable inclusion of the private sector among international and national partners working towards universal education. ${ }^{6}$ Seeking to expand the range of actors involved in contributing to the EFA goals (World Conference on Education for All, 1990) was a logical response in the need to mobilise new resources,

6 'Achieving Education for All will also require more creative and sustained mobilisation of resources from other parts of society, including different levels of government, the private sector and non-governmental organisations.' World Education Forum 2000 website http:// www.unesco.org/education/wef/en-conf/dakframeng.shtm (accessed on 30 March 2014). 
particularly when classic development mechanisms were demonstrating intractable problems. It is now conventional wisdom that public-private partnerships for education (whether bilateral or multi-stakeholder), essentially aimed at increasing the contribution of business and civil society to the provision and monitoring of education at all levels, should be able both to generate new resources and to enrich skills and experience available for educational reform. The UN has embraced public — private partnerships and multi-stakeholder partnerships, as has the World Bank (Patrinos and Sosale, 2007; United Nations Global Compact website in the state of 2007). ${ }^{7}$ UNESCO has courted private sector partners for more than a decade. It has working agreements in the field of education with Microsoft, Varkey GEMS Foundation, Procter \& Gamble, the Packard Foundation, and others. UNESCO had, beginning in 1997 a multi-year programme with the World Economic Forum, has established working relationships and memoranda of understanding on education with a range of multinationals, has endorsed debt conversion development bonds for financing basic education, and has brought out a guide for corporations (UNESCO, 2013).

Unfortunately, the dialogue on the question of public - private partnerships is clouded by both meaning and ideology. ${ }^{8}$ The very concept of partnership means different things to different people. Partnerships can be very different in nature depending on whether they involve business or the not-for-profit private sector. Furthermore, corporate foundations vary greatly in their organisational and funding independence from their corporate founders (Martens, 2007). Partnerships between the public sector and the for-profit private sector in which investment, risks, and benefits are shared equally are rare. Nonprofit contributions from the private sector to education are a tiny proportion of education costs. The overwhelming majority of so-called partnerships are simply sub-contracts by public entities to private firms, with the public sector shouldering most, if not all, of the risk. As for the amounts involved, there is no international tracking of private sector flows of funding for development in general. But except for cases in which all foreign sources of money-including remittances and foreign direct investment-are lumped together, evidence is scarce that the amounts destined for education are significant (van Fleet, 2012).

7 United Nations Global Compact webpage, http://www.unglobalcompact.org.

8 See NORRAG website http://www.norrag.org/en/publications/norrag-news/online-version/ the-new-politics-of-partnership-peril-or-promise/detail/white-knight-or-trojan-horse-theprivate-sector-and-education-for-all-1.html (accessed on 30 March 2014). 
Why does this matter? It matters because as business becomes an accepted and active partner in the development of education policies and management, business interests creep into the formulation of aims and strategy. Furthermore, partnerships are often poorly regulated, with contracts being unclear about ultimate responsibility for problems and failure, and transparency is thus weakened (Utting and Zammit, 2006). Business interests are not, and cannot be, primarily to serve the public good. Long-term investment of businesses is rarely directed towards ensuring equity. Calls for making more of an effort are likely to be heeded, and as a modest contribution to overall education funding, by a small minority of large corporations with deep pockets. The global partnership on development data proposed by the UN's High Level Panel is a case in point, whereby the private sector is to be not a subcontractor but an equal partner in the push to 'develop a global strategy to fill critical gaps, expand data accessibility, and galvanise international efforts to ensure a baseline for post-2015 targets' (High Level Panel on the Post-2015 Development Agenda, 2013, chapter 4).

In recent years a standardised testing mania that began in a few wealthy countries has produced another divide regarding the purposes and potential of education. Proponents of standardised testing are convinced that it contributes to accountability and to improving the relevance of education as well as the performance of individual teachers and of entire schools. Evidence is scarce that this is true. ${ }^{9}$ What is beyond argument is that the education industry now has a powerful financial interest in defending standardised testing, and in expanding it as a method worldwide. This results in, among other things, a narrowing and standardisation of curricula to focus essentially on the subjects covered by tests. Relevance and quality, then, can be defined and driven by what seems amenable to testing.

To be sure, education should be relevant to later life, and the education sector needs to be aware that business can help ensure such relevance. But that relevance should not be entirely decided independently of the learners and their families or standardised for the whole world to make testing simpler. Education is part of the process of preparing for adult life and adapting during adult life to a variety of needs, only one of which is related to the initial workplace. As businesses and corporations become more and more involved in the design of curricula, educational delivery, data collection, and assessment of outcomes, there is a strong risk of shifting priorities towards processes and contents that serve business interests. These interests lie both in having immediately employable school-leavers and in having processes that are profitable.

9 See Diane Ravitch's Blog at http://dianeravitch.net/ (accessed on 30 March 2014). 
The EFA movement has certainly favoured the emergence of a relative unity of discourse among the main international actors, international governmental organisations, bilateral donors, and NGOs. Education as a human right is now the first statement and central argument of most international policy documents on the subject. The reality of permanent crisis in certain countries and between certain countries has now been integrated into the conversation, if not into sums dedicated to development assistance. The spectacular growth of income inequality has caught the attention of observers and features prominently in the yearly EFA Global Monitoring Reports and most of the documents leading up to the establishment of the post-2015 agenda. The World Bank now talks more about learning and less about knowledge (World Bank, 2011). Equity figures prominently in the texts outlining principles. Yet, the discrepancy between the announced aim of poverty reduction and the growth in unequal distribution of wealth is tackled mainly by academics and a few international NGOs. The lack of a general theory of development (McGrath, 2012) and the failure of most mainstream policy documents to consider the perverse effects of reform in the form of privatisation, limiting the role of and space for teacher involvement in reform and choices regarding priorities and the allocation of funds are also an unfortunate common theme.

The main trends affecting our topic in recent years— the equilibrium or lack of it between education as an economic tool and education as a public goodare related to

- widespread advocacy and acceptance of the role of the private sector in both the design and the provision of education;

- trends to generalise international tools of measurement and testing;

- the search for tools that can help education contribute to reducing poverty and unemployment, notably by insisting on the relevance of education to the economy.

The right to quality schooling does not, of course, mean that everyone will obtain equal results. But as with all public goods and services, governments' roles are to mitigate the circumstances that prevent individuals and groups from benefitting equally from schooling and other learning opportunities. While this chapter is not primarily focused on measurable benefits from schooling, it may be useful to examine briefly how the ideology of individual responsibility drives the education agenda and some of the perverse effects of standardised measurement. 
One of the most important features of the last two decades or so is the growth, worldwide, of inequality of income. So, although education has, to a very significant extent, narrowed or even reversed the gender gap in access to schooling, it has not played its expected role in narrowing the gap in human development (United Nations Development Programme, 2013). This growth in inequality calls into question many of the main thrusts of education and development policy worldwide. Education is widely accepted as a human right and research overwhelmingly shows that economic disparities are the most reliable predictors of educational disparities. Yet, measures of learning outcomes are still generally focused on individual success or failure. We are still lacking indicators of progress towards narrowing disparities: in measuring the impact of policies that focus on marginalised groups and individuals.

Much of the contemporary education reform discussion, primarily driven by thinkers, funders, and other influential actors in English-speaking countries, assumes that improving schools can solve most of the problems around the learning outcomes of marginalised groups. Prominent funders of education and development like the World Bank, the Department for International Development (DFID, UK), USAID, focus on improving schools and the school environment. A further assumption is made that unemployment can be tackled by improving the skill sets of the unemployed, mainly by making the content of learning directly relevant to actual or hoped-for employment opportunities. Nearly all the recent papers and declarations leading up to the post-2015 agenda have made these two assumptions. Yet, the evidence is relatively thin to support either (Ravitch, 2013; Shierholz, 2013). Education does not create employment. What learners bring to school, in terms of advantage or disadvantage, is as important as what they find there.

Finally, testing individual learners on subject matter competence has emerged as the principal method for ascertaining the quality of learning and of schools. These processes have the ultimate consequence of failing to address a number of key features of education. Some that one can name are: the functioning of institutions, the social and ethnic composition of institutions that contributes to or detracts from learning, the skills and aptitudes that go beyond individual competence, or the way in which the status and functioning of the education profession impacts education quality. As long as these are treated only as background features, we may miss most of the essential things we need to know. As long as we are primarily testing individuals, there will continue to be winners and losers, and the essence of a complete, quality education for all will not be achieved.

Remedies for inadequate mastery of key skills centre around earlier entry into learning institutions, increased privatisation, or the use of private 
contractors so as to increase choice and/or efficiency, widespread standardised measurement and testing, and placing more responsibility on teachers for learning outcomes. Few of these policy proposals are costed (or calculated by rate-of-return methods for that matter) side-by-side with policy alternatives aimed at tackling fundamental socio-economic inequalities. The perverse effects of the focus on school efficiency (e.g. the narrowing of curricula and the disempowerment of teachers in the wake of widespread high-stakes testing) are not adequately assessed. In spite of widespread agreement that data on education systems and learning outcomes should be disaggregated to track inequality (United Nations, 2013; High Level Panel on the Post-2015 Development Agenda, 2013), we have every reason to fear that this will not happen with the necessary regularity or longevity to inform policies that can reduce the effects of disadvantage. Helping '[...] people build resilience to life's uncertainties' (High Level Panel on the Post-2015 Development Agenda, 2013, Executive Summary) is not the same thing as implementing policies that minimise egregious existing injustices and disparities among people, and even more importantly, groups.

In the meantime, much international data collection is about averages, and not enough about who is being left behind, why that is so, and what evidence there is regarding the effectiveness of measures to combat marginalisation (van Fleet, 2012). Most justifications of education aimed at donors or constituencies of donors are significantly rooted in the notion of education as an investment in human capacity for economic growth.

\section{$7 \quad$ Conclusion}

Clearly, in the push and pull of emphases of the importance of education, all actors shift emphases and attention over time. The UN system tends to favour idealism over messy reality in its policies, moving forward the rights agenda sometimes without enough attention to constraints even while increasingly embracing the notion of partnership with the corporate sector. The inevitable rationing of social services is not a popular theme in UN bodies. The funders, whether the World Bank, the International Monetary Fund (IMF) or bilateral agencies, have constituencies to which they are answerable. These constituencies do not always share the humanistic vision of the UN and have different or divided priorities, even more so when domestic public financing is under strain. Corporations in wealthy donor countries seek Corporations government assistance to reach new markets, and bilateral aid is often used to ease the way. 
As the EFA goals and the Millennium Development Goals approach the 2015 target year, there has been intense activity to prepare the next stages (King and Palmer, 2013). The first proposals of the UN Secretary General's High Level Panel were released in 2013 (High Level Panel on the Post-2015 Development Agenda, 2013), and education was one of the twelve goals proposed.

How and by whom will quality be defined and measured? If the growing pressure for widespread international metrics results in significant expansion of standardised testing developed and administered by corporations, what resources will be diverted from the actual task of ensuring the most marginalised become included? How and by whom will inequality be defined, measured, and collected? Who will be the gatekeepers of the data revolution called for? Will the focus on a few limited outcomes of schooling not lead to a narrowing of the ambitions for education? Will the push for employability lead to a further narrowing of the ambitions for education and the learning experience of most? The answers to these questions will decide much about how the right to education will be offered and by whom it will be exercised.

The World Bank has already announced a major commitment to SABER (Systems Approach for Better Education Results), which intends to cover all the key domains of education (World Bank, 2011); Brookings and UNESCO's Institute for Statistics are moving quickly to flesh out for adoption international metrics for measuring school learning outcomes at all levels and in seven domains (LMTF (Learning Metrics Task Force), 2013); PISA for Development 'aims to increase developing countries' use of PISA assessments for monitoring progress towards nationally-set targets [...] in the post-2015 framework being developed within the UN's thematic consultations.' ${ }^{10}$ Private entities have a lot to gain in the development and marketing of standardised measurement tools. Some have already been intimately involved in the development stages. Standardisation provides much better market opportunities for international corporations than nationally-tailored standards and measurements.

Of the five transformative shifts proposed by the High-Level Panel, the first is 'Leave no one behind'. The only sector that can and might make that happen is the public sector. If the goals of education are to ensure targeted preparation and support to the system so that each person can experience the possibility of discovering her or his own potential, then we need a much stronger commitment and the construction of more complex and differentiated tools for assessing how we are doing. If education is a public good, then it should be non-excludable. We are not there yet, in practice or in philosophy.

10 Programme for International Student Assessment (PISA), http://www.oecd.org/pisa/ aboutpisa/pisafordevelopment.htm (accessed on 30 March 2014). 
It seems reasonably clear that, in the near future at least, the combination of slow growth among donor countries, reduced support for public sector spending and influence, strategic planning for market opportunities by key technology and media corporations, and a desperate search for practical help from the education sector in alleviating poverty and youth unemployment, will favour economically led approaches to education planning. What will likely be missed out, if that is the case, will be policies that aggressively target disadvantage and that treat education, in the words of Jacques Delors, as a means to 'foster a deeper and more harmonious form of human development and thereby to reduce poverty, exclusion, ignorance, oppression and war'.

\section{References}

Adams, A.V., J. Middleton, A. Ziderman (1992) 'The World Bank's policy paper of vocational and technical education and training', Prospects, Vol. 22, pp. 127-40.

Coombs, P.H. (1968) The World Education Crisis: A Systems Analysis. (New York: Oxford University Press).

Delors J. (Chair) (1996) Learning: The Treasure Within, Report to UNESCO of the International Commission on Education for the Twenty-first Century (Highlights) (Paris: UNESCO) http://unesdoc.unesco.org/images/0010/001095/109590eo.pdf (accessed on 1 April 2014).

Emmerij, L. (2010) The Basic Needs Development Strategy, Background paper, World Economic and Social Survey 2010, https://www.un.org/en/development/desa/ policy/wess/wess_bg_papers/bp_wess2010_emmerij.pdf (accessed on 1 April 2014).

Faure, E., et al. (1972) Learning to Be: The World of Education Today and Tomorrow, Report of the Edgar Faure Commission (Paris: UNESCO).

Gajardo, M. (1993) Thinkers on Education: Ivan Illich, originally published in Prospects: the quarterly review of education (Paris: UNESCO) http://www.ibe.unesco.org/ fileadmin/user_upload/archive/publications/ThinkersPdf/illiche.PDF (accessed on 1 April 2014).

Gerhardt, H.-P. (1993) Thinkers on Education: Paolo Freire, originally published in Prospects: the quarterly review of education (Paris: UNESCO), http://www.ibe .unesco.org/fileadmin/user_upload/archive/publications/ThinkersPdf/freiree.PDF (accessed on 26 June 2013).

Global Partnership for Education (2012) Results for Learning Report 2012: Fostering Evidence-Based Dialogue to Monitor Access and Quality in Education (Washington, D.C.: Global Partnership), http://www.globalpartnership.org/content/all-childrenlearning-report-2012-2013 (accessed on 29 April 2012). 
High Level Panel on the Post-2015 Development Agenda (2013) A New Global Partnership: Eradicate Poverty and Transform Economies through Sustainable Development, Report of the High-Level Panel of Eminent Persons on the Post-2015 Development Agenda, http://www.post2015hlp.org/featured/high-level-panelreleases-recommendations-for-worlds-next-development-agenda/ (accessed on 11 June 2013).

Kaul, I., I. Grunberg and M.A. Stern (eds.) (1999) Global Public Goods: International Cooperation in the 21st Century (New York: Oxford University Press), http://web .undp.org/globalpublicgoods/TheBook/globalpublicgoods.pdf (accessed on 1 April 2014).

King, K. and R. Palmer (2013) Post-2015 Agendas: Northern Tsunami, Southern Ripple? The case of Education and Skills, Working Paper 4 (Geneva: NORRAG), http://www .norrag.org/index.php?id=167\&type=0\&juSecure=1\&locationData=167\%3Atx_dam \%3A297\&juHash=947382fffb3ec4ebd9776691bc9c9cb9724cfdce (accessed on 27 October 2013).

Learning Metrics Task Force (LMTF) (2013) Toward Universal Learning: A Global Framework for Measuring Learning, Report No. 2 (Montreal and Washington, D.C.: UNESCO Institute for Statistics and Center for Universal Education at the Brookings Institution), http://www.brookings.edu/research/reports/2013/07/global-frame work-measuring-learning (accessed on 2 August 2013).

Martens, J. (2007) Multistakeholder Partnerships: Future Models of Multilateralism? Potential Pitfalls of Multistakeholder Partnerships (Berlin: Friedrich-Ebert-Stiftung e.V.), http://library.fes.de/pdf-files/iez/04244.pdf (accessed on 29 July 2011).

McGrath, S. (2012) 'Education and Skills Post-2015: What Education; What Development?' NORRAG NewsBite, http://norrag.wordpress.com/2012/09/17/educa tion-and-skills-post-2015-what-education-what-development/ (accessed on 1 April 2014).

Patrinos, H.A. and S. Sosale (eds.) (2007) Mobilizing the Private Sector for Public Education A View from the Trenches (Washington, D.C.: World Bank), http://sitere sources.worldbank.org/EDUCATION/Resources/278200-1099079877269/ 547664-1099079934475/Mobilizing_PrivateSector_PublicEdu.pdf (accessed on 1 April 2014).

Ravitch, D. (2013) 'Stop Blaming Schools for Inequality', authors personal blog, http:// dianeravitch.net/2013/04/29/stop-blaming-schools-for-inequality/ (accessed on 1 April 2014).

Samoff, J. and B. Carrol (2003) From Manpower Planning to the Knowledge Era: World Bank Policies on Higher Education in Africa Prepared for the UNESCO Forum on Higher Education, Research and Knowledge (Paris: UNESCO), http://portal.unesco .org/education/en/file_download.php/d23al68bldbb956f3c63676d5842b6a3Sam off+doc.doc. (accessed on 8 August 2013). 
Samuelson, P.A. (1954) 'The Pure Theory of Public Expenditure', Review of Economics andStatistics, 36(4),pp.387-389,http://links.jstor.orgsici?sici=0034-6535\%28195411 \%2936\%3A4\%3C387\%3ATPTOPE\%3E2.0.CO\%3B2-A (accessed on 1 April 2014).

Secretariat of the World Conference on EFA (1990) Meeting Basic Learning Needs: A Vision for the 1990s World Conference on EFA, Jomtien, 1990, Background document (New York: UNICEF), http://unesdoc.unesco.org/images/0009/000975/097552e. pdf (accessed on 08 August 2013).

Sen, A. (2003) The importance of basic education, Speech to the Commonwealth Education Conference, Edinburgh, http://www.theguardian.com/education/2003/ oct/28/schools.uk4 (accessed on 1 April 2014).

Shierholz, H. (2013) 'We have a demand problem, not a skills problem', Working Economics, http://www.epi.org/blog/high-underemployment-young-college-grads/ (accessed on 1 April 2014).

Spalletti, S. (2008) The History of Manpower Forecasting in Modelling Labour Market (Macerata: University of Macerata), http://www.unimc.it/sviluppoeconomico/ wpaper/wpaper00018/filePaper (accessed on 1 April 2013).

Tilak, J.B.G. (2007a) ‘Best Practice in Education and Training: Hype or Hope?', NORRAG News, No. 39, http://www.norrag.org/es/publications/boletin-norrag/onlineversion/best-practice-in-education-and-training-hype-or-hope.html (accessed on 1 April 2014).

(2007b) 'Rate Of Return To Education: Best Practice?', NORRAG News, No. 39, http://www.norrag.org/en/publications/norrag-news/online-version/best-practicein-education-and-training-hype-or-hope/detail/rate-of-return-to-education-bestpractice.html (accessed on 1 April 2014).

UN Global Compact (2013) UN-Business Partnerships: A Handbook (New York: UN Global Compact), http://www.unglobalcompact.org/docs/issues_doc/un_ business_partnerships/UNBusinessPartnershipHandbook.pdf (accessed on 5 December 2013).

United Nations (2013) Global Thematic Consultation on Education and The Post-2015 Development Framework: Making Education for All a Reality, Beyond 2015 Position paper, www.worldwewant2015.org/file/340073/download/369696 (accessed on 31 October 2013).

United Nations Development Programme (UNDP) (2013) Human Development Report 2013 (New York:UNDP), http://hdr.undp.org/en/reports/global/hdr2013/download/ (accessed on 6 August 2013).

UNDP (1990) Human Development Report 1990 (New York: Oxford University Press), http://hdr.undp.org/sites/default/files/reports/219/hdr_1990_en_complete_nostats .pdf (accessed on 1 April 2014). 
United Nations Educational, Scientific and Cultural Organization (UNESCO) (2013) The Smartest Investment: A Framework for Business Engagement in Education (Paris: UNESCO), http://www.unglobalcompact.org/resources/391 (accessed on 5 November 2013).

UNESCO (2013) Education for All Global Monitoring Report (Paris: UNESCO), http:// www.unesco.org/new/en/education/themes/leading-the-international-agenda/ efareport/ (accessed on 1 April 2014).

Unterhalter, E. (2003) Education, Capabilities and Social Justice, Background paper prepared for the Education for All Global Monitoring Report 2003/4 (Paris: UNESCO), http://www.unesco.org/ulis/cgi-bin/ulis.pl?database=\&lin=1\&futf $8=1 \&$ ll=1\&gp=0\& look=basic\&scl=1\&sc2=1\&ref=http://www.unesco.org/ulis/education/EFA/ GMR_search.html\&nl=1\&req=2\&by=2\&au=Unterhalter,\%20Elaine (accessed on 27 October 2013).

Utting, P. and A. Zammit (2006) Beyond pragmatism: appraising UN-business partnerships What drives the Public Private Partnership phenomenon? (Geneva: United Nations Research Institute for Social Development) http://www.unrisd.org/80256 B3C005BCCF9/httpNetITFramePDF?ReadForm\&parentunid=225508544695E8F3 C12572300038ED22\&parentdoctype $=$ paper\&netitpath $=80256$ B3C005BCCF9 $/$ (httpAux Pages)/225508544695E8F3C12572300038ED22/\$file/uttzam.pdf (accessed on 29 July 2011).

Vally, D. and C.A. Spreen (2012) 'Human Rights in the World Bank 2020 Education Strategy', in Klees, S.J., J. Samoff and N.P. Stromquist (eds.) The World Bank and Education: Critiques and Alternatives (Rotterdam: Sense Publishers), pp. 173-188, https://www.sensepublishers.com/media/1165-the-world-bank-and-education.pdf (accessed on 1 April 2014).

van Fleet, J.W. (2012) Scaling Up Corporate Social Investments in Education: Five Strategies that Work (Washington, D.C.: The Brookings Institution) http://www .brookings.edu/ /media/research/files/papers/2012/5/corporate\%20invest ments\%20vanfleet/05_corporate_investments_vanfleet.pdf (accessed on 20 May 2012).

World Bank (2011) Learning for All: Investing in People's Knowledge and Skills to Promote Development. World Bank Group Education Strategy 2020 (Washington, D.C.: World Bank), http://siteresources.worldbank.org/EDUCATION/Resources/ESSU/ Education_Strategy_4_12_2011.pdf (accessed on 3 April 2014). -(1995) Priorities and Strategiesfor Education:A WorldBankReview, Development in Practice (Washington, D.C.: World Bank), http://siteresources.worldbank.org/ EDUCATION/Resources/278200-1099079877269/547664-1099080118171/ Priorities_and_Strategies_for_Ed_WB_Review.pdf (accessed on 06 July 2013). 
(1971) Education Sector working paper (Washington, D.C.: World Bank), http:// documents.worldbank.org/curated/en/1971/09/700922/education (accessed on 3 April 2014).

World Conference on Education for All (1990) World Declaration on Education for All (Jomtien, Thailand: UNESCO), http://www.unesco.org/education/efa/ed_for_all/ background/jomtien_declaration.shtml (accessed on 29 July 2011). 